\title{
Molecular biology of neuronal voltage-gated calcium channels
}

\author{
Hemin Chin \\ Genetics Research Branch, Division of Basic and Clinical Neuroscience Research, \\ National Institute of Mental Health, National Institutes of Health, Bethesda, Maryland, \\ U.S.A. \\ Accepted 3 August 1998
}

\section{Introduction}

Calcium ions are important intracellular messengers mediating a number of neuronal functions including neurotransmitter release, neurosecretion, neuronal excitation, survival of eurons, and regulation of gene expression. The entry of calcium across the plasmamembrane in response to membrane depolarization or activation of neurotransmitter receptors represents a major pathway for regulating the intracellular level of calcium. While much less is known about the receptor-operated calcium entry mechanism, a remarkable progress has been made in our understanding of the structure, function and regulation of the voltage-gated calcium channels (VGCC). This brief review describes such recent studies on molecular biology of calcium channels, focusing on the involvement of genetic defects in calcium channel genes in neurological diseases.

\section{Molecular diversity and differential expression of calcium channels in the nervous system.}

Multiple types of VGCCs have been identified in neural tissues based upon a combination of biophysical and pharmacological criteria. They are a low voltageactivated (LVA) T-type and high voltage-activated (HVA) $\mathrm{L}-, \mathrm{N}-, \mathrm{P} / \mathrm{Q}-$ and R-type channels. In this section, discussion is focused on the HVA calcium channels and recent cloning of cDNAs encoding a LVA T-type calcium channel will be discussed later. Extensive molecular cloning and bio-chemical efforts in recent years have further defined subunit composition, structural features and functions of each of the subunits associated with HVA calcium channels, and their gene structures (for a review; see Snutch and Reiner, 1992 ; Dunlap et al., 1995 ; Gainer and Chin, 1998). VGCCs are multisubunit complexes composed of the poreforming $\alpha_{1}$ subunit and the accessory $\alpha_{2}-\delta$ and $\beta$ subunits (Figure 1 ).

The cloned $\alpha_{1}$ subunit exhibits structural features common to voltage-gated cation channel gene families and is capable of directing expression of calcium channel activity in heterologous expression systems. In the central nervous system (CNS), VGCCs are expressed by five distinct a1 subunit genes ( $\alpha_{1 \mathrm{~A}}, \alpha_{1 \mathrm{~B}}, \alpha_{1 \mathrm{C}}, \alpha_{1 \mathrm{D}}$ and $\left.\alpha_{1 \mathrm{E}}\right)$, which exhibit further variations due to alternative splicing of the primary RNA transcripts. The $\alpha_{1 \mathrm{C}}$ and, $\alpha_{1 \mathrm{D}}$ subunit genes encode dihydropyridine (DHP)-sensitive L-type channels, while the three other $\alpha_{1}$ subunit genes $\left(\alpha_{1 \mathrm{~A}}\right.$, $\alpha_{1 \mathrm{~B}}$ and $\left.\alpha_{1 \mathrm{E}}\right)$ give rise to DHP-insensitive P/Q-, N- and R-type channels, respectively. The $\alpha_{2}$ and $\delta$ subunit proteins are produced by proteolytic cleavage of a larger precursor produced by the single $\alpha_{2}-\delta$ gene (Table 1 ). Three alternatively spliced variants of the $\alpha_{2}$ subunit are expressed in a tissue-specific manner. Two variants have been isolated from the brain and skeletal muscle (Kim et al., 1992; Williams et al., 1992), and a distinct third splice variant which is expressed in glial cells has been recently identified (Puro et al., 1996). In addition to the gene encoding the skeletal muscle $\beta_{1}$ subunit, three other $\beta$ subunit genes ( $\beta 2, \beta 3$ and $\beta 4$ ) have been isolated thus far. Like the $\alpha_{1}$ subunits, differential splicing of the primary transcripts from the $\beta$ subunit genes generate multiple isoforms (Table 2).

The expression of cloned calcium channel by using $\alpha_{1}$ subuit alone or in combination with $\alpha_{2}$ and $\beta$ subunits in heterologous expression systems such as Xenopus oocytes has allowed for the assessment of the roles and contributions of the accessory subunits in channel func-tion. Electrophysiological and biochemical characteristics of the expressed calcium channels are greatly influenced by the coexpressed $\beta$ subunits (Sather et al., 1993). In fact, different combinations of the diverse $\alpha_{1}, \alpha_{2}$ and $\beta$ subunit transcripts in a cell could provide a possible mechanism to generate various calcium channel properties observed in the CNS.

The transcripts encoding HVA calcium channel subtypes are differentially localized in different regions of the brain and as well as in individual neurons within the specific brain regions. While $\omega$-contotoxin-sensitive $\mathrm{N}$ type channels encoded by $\alpha_{1 \mathrm{~B}}$ gene is widely expressed throughout adult rat brain, DHP-sensitive L-type and $\mathrm{P} / \mathrm{Q}$-type channels, encode by $\alpha_{1 \mathrm{D}}$ gene and $\alpha_{1 \mathrm{~A}}$ genes respectively, exhibit distinct patterns of their mRNA expression (Figure 2). As previously noted (Chin et al., 1992a), the $\alpha_{1 \mathrm{D}}$ transcripts are predominantly expressed in the brain regions important for neuroendocrine function such as pituitary and pineal gland, and olfactory bulb and dentate gyrus of hippocampus. In contrast, the $\alpha_{1 \mathrm{~A}}$ transcripts are most abundant in the pyramidal cells of CA3 region of hippocampus and the Purkinje and granule cells of cerebellum. However, expression patterns of VGCC subtypes at the cellular level are much more complex in 
(a)

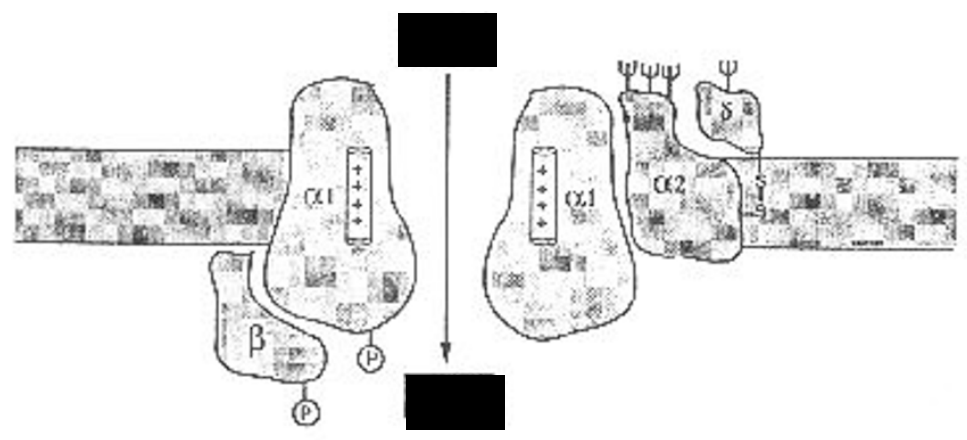

(b)

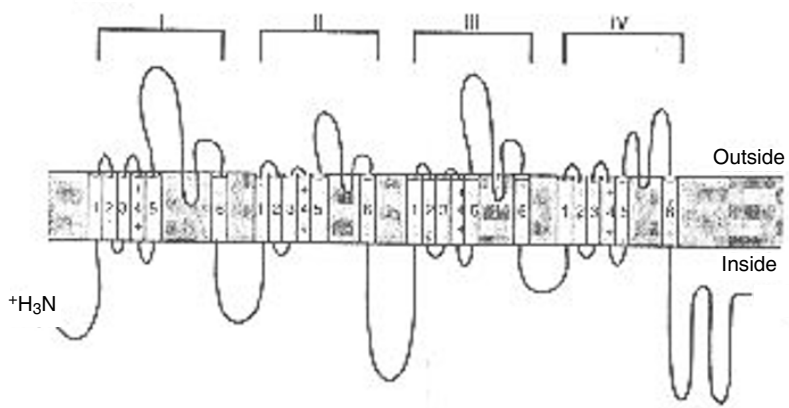

Figure 1. Calcium channel subunit structures. (a) The subunits of a DHP-sensitive Ltype calcium channel are illustrated. The pore-forming a1 subunit contains hydrophobic =transmembrane domains. The putative voltage-sensing domain (S4) are also indicated as + charges. The $\alpha_{2}$ and $\delta$ polypeptides are heavily glycosylated and are linked to one another by disulfide bonds (-S-S-). The b subunit proteins are cytoplasmic. The primary structure of the $\alpha_{1}$ and $\beta$ subunit cDNAs indicate that there are multiple consensus sequences for phosphorylation by various protein kinases as indicated by circled P's (adapted from Gainer and Chin, 1998). (b) Membrane topology of individual calcium channel subunits as determined by primary structure analysis. Cylinders $\alpha 2-\delta$ Subunit

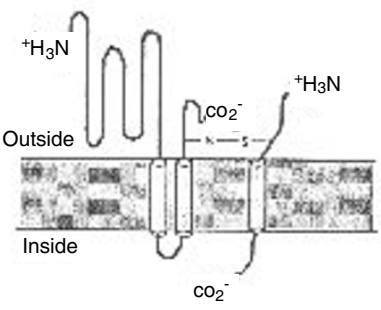

$\beta$ Subunit

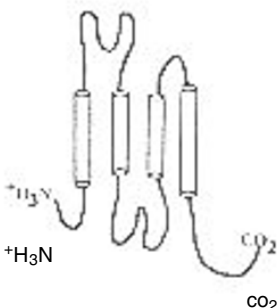

represent predicted a helical segments. The $\alpha_{1}$ subunit consists of four repeating homologous units, indicated by the Roman numerals. Each of these contains six transmembrane a helical segments. The fourth a helical segment of each repeating unit (indicated with + charges) contains a positively charged amino acid (either lysine or arginine) in every third position and is involved in voltage-sensing. The $\alpha_{2}$ and $\delta$ polypeptides are products of a single gene and are post-translationally cleaved and linked by a disulfide bond. The cytoplasmic $\beta$ subunit is peripherally associated with the a1 subunit as shown in a.

Table 1 The Pore-Forming $\alpha 1$ Subunit Genes and Their Splice Variants. Data adapted from Dunlap et al.,1995. Abbreviations: HVA,MVA or LVA are high, medium, or low voltage activated current, respctively.

\begin{tabular}{|c|c|c|c|c|c|}
\hline Gene & Electrophysiology & $\begin{array}{l}\text { Phamacological } \\
\text { Blocker }\end{array}$ & $\begin{array}{l}\text { Splic } \\
\text { Variants }\end{array}$ & Location & $\begin{array}{l}\text { GenBank Accession } \\
\text { No/References }\end{array}$ \\
\hline$\alpha 1 \mathrm{~A}$ & HVA,P-or Q-type & $\begin{array}{l}\omega \text {-Agatoxin IVA, } \\
\omega \text {-Conotoxin MVIIC }\end{array}$ & $\begin{array}{l}\mathrm{Bl}-1 \mathrm{a} \\
\mathrm{Bl}-1 \mathrm{~b} \\
\mathrm{Bl}-2 \mathrm{a} \\
\mathrm{Bl}-2 \mathrm{~d}\end{array}$ & brain,kidney & $\begin{array}{l}\text { X57476 (Mori et al.,1991) } \\
\text { X57688 } \\
\text { X57477 } \\
\text { X57689 }\end{array}$ \\
\hline$\alpha 1 \mathrm{~B}$ & HVA,N-type & $\omega$-Conotoxin GIVA & $\begin{array}{l}\alpha 1 \mathrm{~B}-1 \\
\alpha 1 \mathrm{~B}-2\end{array}$ & $\begin{array}{l}\text { brain } \\
\text { brain }\end{array}$ & $\begin{array}{l}\text { M94172 } \\
\text { M94173 }\end{array}$ \\
\hline$\alpha 1 C$ & HVA,L-type & DHP & $\begin{array}{l}a, r b C-I \\
b, r b C-I I \\
c \\
d\end{array}$ & $\begin{array}{l}\text { heart,brain } \\
\text { heart,brain } \\
\text { heart } \\
\text { heart }\end{array}$ & $\begin{array}{l}\text { M67516 } \\
\text { M67515 } \\
\text { J05675 } \\
\text { Perez-Reyes et al. (1990) }\end{array}$ \\
\hline$\alpha 1 D$ & HVA,L-type & $\mathrm{DHP}$ & $\begin{array}{l}a \\
b \\
c \\
d\end{array}$ & $\begin{array}{l}\text { brain, } \\
\text { endocrine cells }\end{array}$ & $\begin{array}{l}\text { M76558 } \\
\text { Perez-Reyes et al. (1990) }\end{array}$ \\
\hline$\alpha 1 S$ & HVA,L-type & $\mathrm{DHP}$ & $\begin{array}{l}a \\
b\end{array}$ & skeletal muscle & $\begin{array}{l}\text { M23919 } \\
\text { Perez-Reyes et al. (1990) }\end{array}$ \\
\hline$\alpha 1 E$ & $\begin{array}{l}\text { MVA- } \\
\text { P-type }\end{array}$ & $\mathrm{Ni}^{2+}$ & $\begin{array}{l}\text { E-1 } \\
\text { E-2 } \\
\text { E-3 } \\
\text { E-4(?) }\end{array}$ & brain & $\begin{array}{l}\text { L29384 } \\
\text { L15453 } \\
\text { L29385 } \\
\text { Williams et al. (1994) }\end{array}$ \\
\hline
\end{tabular}




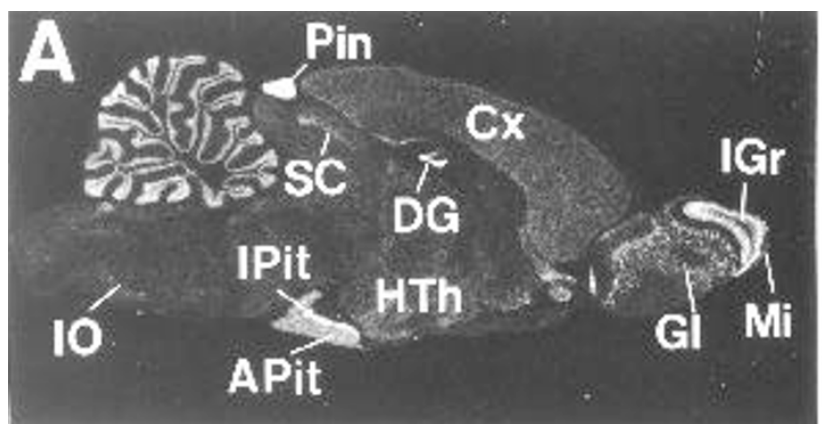

Figure 2. Localization of the L-type $\alpha_{1 D}(\mathrm{~A})$ and P/Q-type $\alpha_{1 \mathrm{~A}}$ (B) subunits of calcium channels in adult rat brain by in situ hybridization. Negative film autoradiography of in situ hybridization of parasagittal sections. Apit, anteriro lobe of pituitary gland; $\mathrm{Cb}$, cerebellum; Cpu, caudate putamen; Cx, cerebral cortex; DG, dentate gyrus; $\mathrm{GI}$, glomelular layer of olfactory bulb; Hip, hippocampus; HTh, hypothalamus; IC, inferior

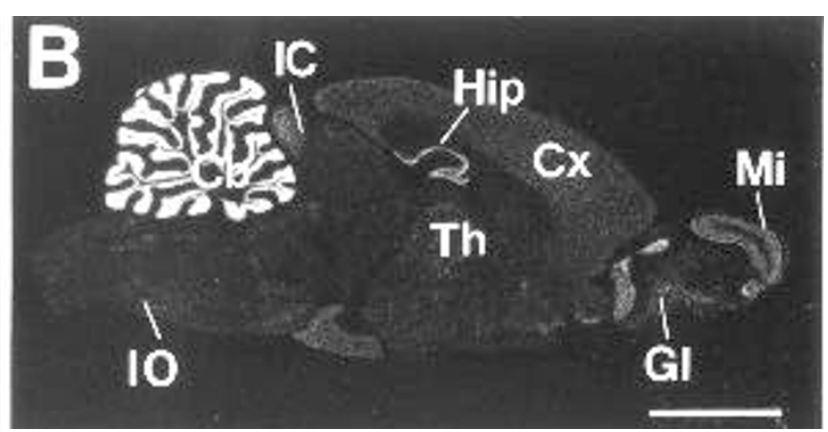

colliculus; Igr, internal granular layer of olfactory bulb; IO, inferior olive; Ipit, intermediate lobe of pituitary gland; Mi, mitral cell layer; Pin, pineal gland; SC, superior colliculus; Th, thalamus, Bar represents $0.5 \mathrm{~cm}$.

Table 2 Splice variants for the Grenes Encoding $\alpha 2-\delta$ and $\beta$ Subunits. Data adapted from Dunlap et al.,1995.

\begin{tabular}{|c|c|c|c|c|}
\hline Subunits & Gene & $\begin{array}{l}\text { Splice } \\
\text { Variants }\end{array}$ & Location(Transcript size) & $\begin{array}{l}\text { GenBank Accession } \\
\text { No/Reference }\end{array}$ \\
\hline \multirow[t]{3}{*}{$\alpha 2-\delta$} & $\alpha 2$ & $\alpha 2 s$ & skeletal muscle & M21948 \\
\hline & & $\alpha 2 b$ & brain & M86621 \\
\hline & & $\alpha 2 m$ & Muller glain & Puro et al (1996) \\
\hline \multirow[t]{11}{*}{$\beta$} & $\beta 1$ & $\beta 1 a$ & skeletal muscle (3.4 kb) & M25817;M92391 \\
\hline & & $\beta 1 b$ & brain $(3,4 \mathrm{~kb})$ & X61394,M92392 \\
\hline & & $\beta 1 c$ & brain & M92393 \\
\hline & $\beta 2$ & $\beta 2 a$ & heart (3.5 kb) & M80545,X64297 \\
\hline & & $\beta 2 b$ & brain (4 kb) & X64298 \\
\hline & & $\beta 2 c$ & & X64299 \\
\hline & & $\beta 2 d$ & & \\
\hline & $\beta 3$ & $\beta 3 а$ & brain (2.7 kb) & X64300;X76555 \\
\hline & & $\beta 3 b$ & brain (3 kb) & X76556 \\
\hline & & $\beta 3 c$ & brain $(3.5 \mathrm{kd})$ & \\
\hline & $\beta 4$ & $\beta 4$ & cerebellum, kidney (7 kd) & L02315 \\
\hline
\end{tabular}

that multiple VGCC subunit mRNAs are expressed by individual neurons. A recent study of single-cell gene expression in magnocellular neurons in the hypothalamus reveals that nearly all of the known calcium channel subunit transcripts are present, albeit at different levels, in both vasopressin and oxytocin expressing cells (Glasgow et al., 1998)

Given the complexity of calcium channel subunits at the molecular level, i.e., the existence of multiple splice variants for the subunits, the combinatorial heterogeneity of the channel subunits expressed in neurons, and the differential cellular and subcellular compartmentalization of theses assemblies (e.g., in dendrites, somata, and axon terminals), it will be essential in the future to correlate the specific $\alpha$ and $\beta$ subunits forms in a given cell with the specific properties of its calcium currents. Availability of the methods of correlative single-cell gene expression and patch electrode analysis (Eberwine et al., 1992; Monyer and Lambolez, 1995) should make such studies feasible.

\section{The regulation of calcium channel gene expression}

Molecular insights into how distinct calcium channel subtypes are expressed in a tissue-or cell-type specific manner can be gained by examining mechanisms under-lying regulation of their expression at transcriptional level. In this regard, the restricted expression of the $\mathrm{N}$-type $\alpha_{1 \mathrm{~B}}$ gene in the CNS and wide distribution of the L-type $\alpha_{1 D}$ subunit transcript within the CNS and in a variety of other tissues present an 
excellent opportunity to examine and compare molecular bases governing calcium channel gene expression. Indeed, the studies on the promoters of the two $a_{1}$ subunit gene utilizing a variety of molecular biologic approaches, such as 5'-upstream sequence analysis, deletion analyses using promoter-reporter fusion gene constructs, DNase I foot-printing and electrophoretic mobility assays, have indicated that their expression is differentially regulated at trans-criptional level. The 4.0-kb 5'-flanking sequence of the $\alpha_{1 \mathrm{~B}}$ gene contained a promoter which is capable of directing expression of the $\alpha_{1 \mathrm{~B}}$ transcript in neuronal cells and repressing its expression in non-neuronal cells (Kim et al., 1997).Further deletion analysis of $\alpha_{1 \mathrm{~B}}$ subunitluciferase fusion gene constructs located acis-acting repressor in the distal upstream region. Careful inspection of the sequence in this region did not identify any nucleotide sequence with a significant degree of homology to canonical sequence of the neural-restrictive-silencerelement (NRSE) found in many neuron-specific genes (Schoenherr et al., 1996). New negative regulatory elements, in addition to the NRSE, for neural genes have been reported, and future study will reveal identity of a repressor element present on the $\alpha_{1 \mathrm{~B}}$ gene.

The transcription of the L-type $\alpha_{1 D}$ gene is regulated by both cis-acting positive and negative elements in the 5 ' promoter region. Consistent with the broad mRNA expression within and outside of the CNS, a repressor element is not found in the promoter region of the $\alpha_{1 D}$ gene. Interestingly, DNase I foot printing, gel mobility shift assay of exon 1 of the $\alpha_{1 D}$ gene revealed a DNA binding region that included sequence. This $(A T G)_{7}$ trinucleotide repeats functions as a novel enhancer in vitro when linked to a thymidine kinase promoter and a CAT reporter gene (Kamp et al., 1995). Whether or not the $(\mathrm{ATG})_{7}$ trinucleotide repeats work in vivo as an enhancer for the endogenous promoter is an interesting topic for future investigation.

\section{Functions of calcium channels}

Influx of calcium through VGCCs localized in different subcellular compartments within the nerve cells mediates a variety of distinct cellular functions in the nervous systems. Calcium ions taken up by the L-type channels on the cell body, through cascades of signaling pathways, are implicated in the regulation of gene expression, whereas increases in localized calcium level in the presynaptic terminals are coupled to excitation-secretion coupling mechanisms. The mechanisms by which calcium influx through VGCCs is linked to neurotransmitter release have been elucidated by identifying proteins that are involved in trafficking, docking and fusion of vesicles, and by characterizing their protein-protein interactions during calcium-evoked exocytosis. These studies have led to a conceptual framework known as the "SNARE" hypothesis (Sollner et al., 1993), and extensive homology cloning efforts have yielded very large number of proteins and their respective isoforms with which to construct various models of secretion. Briefly, the term SNARE refers to soluble $\mathrm{N}$-ethylmaleimide-sensitive fusion (NSF) protein receptors which may be present on either vesicles (v-SNARE) or targets (t-SNARE), such as the plasma-memrane. The NSF and SNAPs (soluble NSF attachment proteins, e.g., $\alpha, \beta$ and $\gamma$ SNAPs) are believed to be key players in the vesicular docking, priming, and fusion processes (for recent reviews, see Calakos and Scheller 1996; Sudof, 1995; Augustine et al., 1996).

$\omega$-conotoxin GVIA-sensitive N-type channels bind to syntaxin, one of the t-SNAREs present on the presynaptic membranes, thereby placing the VGCC in molecular proximity to the proposed SNARE complexes which included SNAP-25 and synaptotagmin (Bennet et al., 1992; Leveque, et al., 1994). P/Q-type VGCCs have also been shown to co-immunoprecipitate with syntaxincontaining SNARE complexes in rat cerebellar synaptosomes (Martin et al., 1996). A peptide motif on $\mathrm{N}$-or P/Q-type VGCC (termed 'synprint' site) that binds to syntaxin in a calcium-dependent manner was found (Sheng et al., 1995). A functional consequence of this molecular coupling was subsequently demonstrated in a study where injection of $\mathrm{N}$-type calcium channel synprint peptide into superior cervical ganglion neurons resulted in a dramatic reduction in fast neurotransmitter release (Mochida et al., 1996). This interaction appears to have another regulatory function in that co-expression of syntaxin and N- or P/Q-type VGCC in Xenopus oocytes modified gating properties of the expressed channels (Bezprozvanny et al., 1995; Weiser et al., 1996).

Although much less is known about the molecular mechanisms of peptide and hormone secretion, it is generally believed that the basic mechanisms underlying secretion will be universal and thus the molecular machinery would be conserved between SSV and LDCV secreting systems (Martin, 1994). Diverse isoforms of vSNAREs and t-SNAREs identified in neurons have shown to be expressed in LDCV containing neuroendocrine and endocrine cells using a combination of RT-PCR, in situ hybridization histochemistry, Western Blot, and clostridial toxin analyses. Synaptophysin, rab3b, synaptotagin I/III, munc-18, VAMP-2, CSP, NSF, $\alpha$-SNAP, SNAP-25, and syntaxin are present in the pituitary gland (Jacobsson and Meister, 1996). VAMP-2, SNAP-25, syntaxin, synaptotagmin III, and munc-18 are also found in pancreatic islets and $\beta$ cells, and the proteolytic cleavage of VAMP-2 in HITT15 cells inhibited calcium-evoked insulin secretion (Wheeler et al., 1996).

\section{Diseases linked to calcium channels and mouse mutations with known}




\section{defects in calcium channel genes}

During the last few years, much progress has been made in understanding the molecular genetic bases for human diseases and mutations in mouse that are linked to defects in calcium channels. They can be divided into three groups; channelopathies that are due to defects in calcium channels in the muscle tissues, those disorders and mutations stemming from abnormality in neuronal calcium channel genes, and autoimmune diseases associated with calcium channels.

Cloning of skeletal muscle a1s subunit gene and subsequent mapping of its location in human and mouse genomes have led to isolation and characterizations of human diseases and mouse mutations caused by skeletal muscle calcium channel defects. Hypokalemic periodic paralysis (HoPP) is associated with three mutations in the a1s subunit gene located on chromosome 1 (1q31 32) (Jurkat -Rott et al., 1994; Ptacek et al., 1994). Two of these affect the outermost argine in the S4 helices of $\mathrm{D} 2$ and $\mathrm{D} 4(\mathrm{R} 528 \mathrm{H}$ and $\mathrm{R} 1239 \mathrm{H})$ accounting for the majority of families with HoPP, while the thrid mutation $\mathrm{R} 1239 \mathrm{G}$ is seen rarely. The lethal autosomal recessive mutation muscular dysgenesis (mdg) phenotype, which results in total lack of excitation-contraction coupling in all homozygous dysgenic offspring (Pai, 1965), can be rescued by microinjection of a cloned $\alpha_{1 s}$ subunit cDNA in noncontracting $\mathrm{mdg} / \mathrm{mdg}$ primary muscle cultures (Tanabe et al., 1988). Mdg mutation is caused by mutations in the $\alpha_{1 s}$ subunit gene located on mouse chromosome 1 (Chin et al., 1992b).

Molecular genetic studies of neuronal VGCCs have yielded evidence for a number of interesting mechanisms that link channel gene defects to diseases of mice and men. The best-characterized cases, thus far, is those channelopathies associated with the P/Q-type $\alpha_{1 \mathrm{~A}}$ subunit gene. Ophoff and his colleagues (1996) cloned a gene on chromosome 19, which are linked to the two rare forms of human neurological disorders: familial hemiplegic migraine (FHM) and episodic ataxia type-2 (EA-2). FHM is a rare autosomal dominant subtype of migraine, which is associated with, in some families, progressive cerebellar atrophy. EA-2 is another autosomal dominant paraxysmal cerebral disorder, which is characterized by cerebellar ataxia migraine-like symptoms, and cerebellar atrophy. Mis-sense mutations scattered along the entire coding region are found in individuals with FHM and splice site mutation in EA-2 patients, which leads to a truncated $\alpha_{1 A}$ subunit protein. More recently, a slowly progressing autosomal dominant form of cerebellar ataxia, termed spinocerebellar ataxia type 6 (SCA6), is found to be associated with CAG trinucleotide expansion in the a1A subunit gene (Zhuchenko et al., 1997). A five-base pair (GGCAG) insertion prior to the previously detected stop codon in combination with a 36-base pair deletion in the a1 A subunit gene would produce a diverse molecular forms of $\alpha_{1 \text { A }}$ protein whose $3^{\prime}$ carboxy-termini extended beyond the normal $\alpha_{1 A}$ subunit protein. It would be of great interest to examine biophysical properties of calcium channels expressed by these extended versions of the $\alpha_{1 \text { A }}$ subunit gene and their possible roles in normal and pathophysiological neuronal functions.

The mouse mutant phenotype of tottering $(\mathrm{tg})$ and leaner are associated with defects in the $\alpha_{1 A}$ subunit gene. The $t g$ mice exhibit severe ataxia, Petit-mal-like epilepsy and a myoclonus-like movement disorder, and the leaner mutation in an allele of $\operatorname{tg}\left(\mathrm{tg}^{\mathrm{la}} / \mathrm{tg}^{\mathrm{la}}\right)$ causes profound chronic ataxia associated with cerebellar atrophy resulting from pervasive loss of Purkinje and granule cells. These mutants have been found to carry an autosomal recessive mutation in a splice donor consensus sequence in the $\alpha_{1 \mathrm{~A}}$ subunit gene, which is not surprising in that the $P / Q$-type channels are the most abundant VGCC subtype expressed in cerebellar Purkinje and granule cells. The aberrant splicing of intron/exon junctions results in truncation of the normal open reading frame and is thought to give rise to two $\alpha_{1 \mathrm{~A}}$ splice variants with novel carboxy-terminal sequence (Fletcher et al., 1996). Examination of $\alpha_{1 \mathrm{~A}}$ transcript and protein expression, by in situ hybridization and immunocytochermistry, in the leaner and age-matched control mice show no quantitative differences in their levels in cerebellar Purkinje and granule cells (Lau et al., 1998). HVA calcium currents carried by $\mathrm{P}$-type channels, however, are reduced in acutely isolated leaner ( $\left.\operatorname{tg}^{\mathrm{la}} / \mathrm{tg}^{\mathrm{la}}\right)$ Purkinje cells exhibit as compared to Purkinje cells from age-matched control mice (Dove et al., 1997; Lorenzon, et al., 1998). The specific cause for the reduction in $\operatorname{tg}^{\text {la }} / \mathrm{tg}^{\text {la }}$ Purkinje cells calcium current remains to be determined.

In addition to the $\alpha_{1 \mathrm{~A}}$ and $\alpha_{1 \mathrm{~s}}$ genes, there are indications that other pore-forming a1 subunits (i.e., $\alpha_{1 B}$ or $\alpha_{1 E}$ ) and ancillary $\beta$ subunit might all play a role in other disease states in human and mouse mutations. For example, the Lambert-Eaton myasthenic Syndrome (LES) is an autoimmune disorder of neuromuscular transmission, of which clinical phenotypes include muscle weakness caused by reduction in acetylcholine release from presynaptic terminals innervating muscle tissues. As shown in other congenital myasthenic syndromes such as Myasthenia gravis and acquired neuromyotonia which are also often associated with Thyoma, LES is often associated with small-cell lung carcinoma (SCLC). This observation probably reflects the host immune response against components on tumor cells. The circulating antibodies against $\alpha_{1 \text { A subunit }}$ protein, and to a lesser degree, $\beta_{1 \mathrm{~B}}$ subunit protein of the N-type calcium channels, are found in LES patients (Lennon et al., 1995). Moreover, antibodies directed against the peptide corresponding to the unique acidic stretch in the IV S5-S6 linker region of $\alpha_{1 \mathrm{~A}}$ subunit, inhibited calcium currents in SCLC, suggesting that a 
possible important role for $\alpha_{1 \mathrm{~A}}$ calcium channels in the pathogenesis of LES.

The first clue that $\beta_{4}$ subunit gene is linked to lethargic mutation in mouse has come from a genetic mapping study showing that mouse $\beta_{4}$ gene maps closely to lethargic locus on chromosome 2 (Chin et al., 1995). Subsequently, it has been shown that there is a fournucleotide insertion in $\beta_{4}$ subunit gene in the lethargic mouse resulting in a splicing error that give rise to a severely truncated $\beta_{4}$ protein (Burgess et al., 1997). The $\beta_{4}$ subunit is present abundantly in cerebellum, and temporal pattern of its mRNA expression closely resemble that of $\alpha_{1 \mathrm{~A}}$ transcripts (Kim and Chin, 1997). This truncated $\beta_{4}$ subunit protein, which contains $\sim 40 \%$ of the amino-terminal portion, is missing the site that interacts with the a1 A subunit proteins, thus is unable to form fully functional channels. Lack of mature $\beta_{4}$ protein in lethargic mouse might result in dysfunctional calcium channels in cerebellar Purkinje and granule cells, and thus underlie observed phenotypes of ataxia and bsencelike seizures, similar to the tottering mouse.

\section{Future Direction}

While a diversity of neuronal calcium channel had been appreciated from electrophysiological analyses of VGCCs found in excitable cells, the genetic and biochemical diversity of these molecules has proven greater than anticipated. With this expanded knowledge of the structure and function of neuronal VGCCs, we are well poised to devise innovative strategies not only to identify novel calcium channel subtypes and their specific inhibitors, but also to define the molecular determinants of functional modulation of the channels.

With regard to the first point, there is no other instance that the power and utility of genome sequencing initiative is better exemplified than the recent cloning of a T-type calcium channels (Perez-Reyes et al., 1998). In contrast to HLA calcium channels, the molecular entity of LVA Ttype calcium channels, despite of their well-characterized biophysical properties, has been a subject of intense discussion. While some suggested that $\alpha_{1 E}$ gene constitutes a pore-forming subunit of a LVA channel based on their expression studies in Xenopus oocytes (Soong et al., 1993), others reported that LVA currents are expressed in mouse neuroblastoma cell lines in the absence of $\alpha_{1 \mathrm{E}}$ mRNA, suggesting that these channels comprise a distinct molecular class (Gottschalk et al., 1996). PerezReyes and his colleagues have taken a different cloning approach that utilized the wealth of information available in the Caenorhabditis elegans genome database. Search of $\mathrm{C}$. elegans expressed sequence tag (EST) database with a homology probe derived from a highly conserved region of calcium channel a 1 subunits has led them to identification and cloning of a novel family of cDNAs encoding LVA T-type calcium channels. Isolation of this T-type channel cDNA undoubtedly will lead to isolation of a new and important family of LVA VGCCs and identifi-cation of a new class of pharmacological inhibitors and therapeutical reagents specific for the T-type channels. Availability of genomic databases and genetic mapping databases will provide new research tools for channel discovery and analysis of channel functions that are complementary to standard"wet bench approach".

A second area of research in calcium channel field will continue to be elucidation of molecular and cellular bases of calcium channel functions. We still do not fully understand how distinct calcium channel subtypes are assembled and targeted to different cellular compartments (soma, dendrites, and axon terminals), Nor do we know how calcium channel subtypes play key roles in signal transduction and plasticity in developing, mature, and aging nervous systems through interactions with other cellular proteins.

\section{Acknowledgements}

I wish to thank collaborators and colleagues who have contributed a great deal to the work described here. They are; Drs. Louise C. Abbott, Harold Gainer, Wolfram Gottschalk, Juck-Joon Hwang, Hyung-Lae Kim, Hyun Kim, Hyun-Ho Jung, Dong Sun Kim, Christine A. Kozak, Oh-Joo Kwon, Donald G. Puro, and Elis F. Stanley.

\section{References}

Augustine, G. J., Burns, M. E., DeBello, W. M., Pettit, D. L. and Schweitzer, F. E. (1996) Exocytosis: proteins and perturbation. Ann. Rev. Pharmacol. Toxicol. 36: 659-701

Bennett, M. K, Calakos, N. and Scheller, R. H. (1992) Syntaxin: a synaptic protein implicated in the docking of synaptic vesicles at presynaptic active zones. Science 257 : 255-259

Bezprozvanny, I., Scheller, R. H. and Tsien, R. W. (1995) Functional impact of syntaxin on gating of N-type and Q-type calcium channels. Nature 378: 623-626

Burgess, D. L., Jones J. M., Meisler, M. H. and Noebels, J. L. (1997) Mutation of the $\mathrm{Ca} 2+$ channel beta subunit gene $\mathrm{Cchb} 4$ is associated with ataxia and seizures in the lethargic (Ih) mouse. Cell 88: 385-392

Calakos, N. and Scheller, R. H. (1996) Synaptic vesicle biogenesis, docking and fusion: A molecular description. Physiol. Rev. 76: 1-29

Chin, H., Smith, M. A., Kim, H.-L. and Kim, H. (1992a) Expression of di-hydropyridinesensitive brain calcium channels in the rat central nervous syste. FEBS Letters 299: 6974

Chin, H., Krall, M., Kim, H.-L., Kozak, C. A. and Mock, B. (1992b) The gene for the $\alpha_{1}$ subunit of the skeletal muscle dihydropyridine-sensitive calcium channel (CChl1a3) maps to mouse chromosome 1. Genomics 14: 1089 -1091

Chin, H., Kwon, O.-J., Jung, H. H., Kim, D. S. and Kozak, C. A. (1995) Genetic mapping of the mouse genes encoding the voltage-sensitive calcium channel subunits. Genomics 28: 592-595

Dove, L. S., Abbott, L. C. and Griffith, W. H. (1997) High voltage-activated calcium currents are reduced in cerebellar Purkinje cells from the leaner mutant mouse. Soc. Neurosci.Abst. 23: 2013

Dunlap, K., Luebke, J. I. and Turner, T. J. (1995) Exocytotic $\mathrm{Ca}^{2+}$ channels in mammalian 


\section{neurons. TINS 18: 89-98}

Eberwine, J., Yeh, H., Miyashiro, K., Cao, Y., Nair, S., Finnel, R., Zettel, M. and Coleman, P. (1992) Analysis of gene expression in single live neurons. Proc. Natl. Acad. Sci. USA 89: 3010 -3014

Fletcher, C., Lutz, C.M., O'Sullivan, T.N., Shaughnessy, Jr. J. D., Hawkes, R., Frankel, W. N., Copeland, N. G. and Jenkins, N. A. (1996) Absence epilepsy in tottering mutant mice is associated with calcium channel defects. Cell 87: 607-617

Gainer, H. and Chin, H. (1998) Molecular diversity in neurosecretion: reflections on the hypothalamo-neurohypophysial system. Mol. Cell. Neurobiol. 18: 209-227

Glasgow, E., Yamashita, M., Kusano, K., Chin, H. and Gainer, H. (1998) Analysis of differential gene expression in magnocellular oxytocin and vasopressin neurons. Soc. Neurisci. Abstr. 24 (In press)

Gottschalk, W., Kim, D. S., Gilbert, D., Chin, H. and Stanley, E. F. (1996) A neuroblastoma T-type calcium channel in the absence of a1E mRNA. Soc. Neurosci. Abstr. Vol. 22 , Part 1, p. 5

Jacobson, G. and Meister, B. (1996) Molecular components of the exocytotic machinery in the rat pituitary gland. Endocrinology 137: 5344-5356

Jurkat-Rott, K., Lehmann-Horn, F., Elbaz, A., Heine, R., Gregg, R. G., Hogan, K., Powers, P. A. (1994) A calcium channel mutation causing hypokalemic periodic paralysis. Hum. Mol. Gent. 3: $1415-1419$

Kamp, T. J., Mitas, M., Fields, K. L., Asoh, S., Chin, H., Marban, E. and Nirenberg, M. (1995) Transcriptional regulation of the neuronal L-type calcium channel $\alpha_{1 D}$ subunit gene. Cell. Mol. Neurobiol.15: 301-325

Kim, H.-L., Kim, H., Lee, P., King, R. G. and Chin, H. (1992) Rat brain expresses an alternatively spliced form of the dihydropyridine-sensitive L-type calcium channel $\alpha_{2}$ subunit. Proc. Natl. Acad. Sci.USA 89: 3251-3255

Kim, D. S. and Chin, H. (1997) Coordinated spatial and temporal expres-sion of voltagesensitive calcium channel $\alpha_{1 A}$ and $\beta_{4}$ subunit mRNAs in rat cerebellum. Korean J. Biol. Sci. 1, 589-594

Kim, D. S., Jung, H.-H., Park, S.-H. and Chin H. (1997) Isolation and characterization of ther 5 '-upstream region of the human $\mathrm{N}$-type calcium channel $\alpha_{1 \mathrm{~B}}$ subunit gene. J. Biol. Chem. 272: 5098-5104

Lau, F. C., Abbott, L. C., Rhyu, I. J., Kim, D. S. and Chin, H. (1998) Expres-sion of calcium channel $\alpha_{1 \mathrm{~A}}$ RNA and protein in the leaner mouse $\left(\operatorname{tg}^{\mathrm{la}} / \operatorname{tg}^{\mathrm{la}}\right)$ cerebellum. Mol. Brain Res. (in press)

Lennon, V. A., Kryzer, T. J., Griesmann, G. E., O'Suilleabhain, P. E., Windebank, A. J., Woppmann, A., Miljanich, G. P. and Lambert, E. H. (1995) Calcium-channel antibodies in the Lambert-Eaton syndrome and other paraneoplastic syndromes. N. Engl. J. Med. 332: $1467-1474$

Leveque, C., Oussama, E. F, Martin-Moutot, N., Sato, K., Kato, R., Takahashi, M. and Seagar, M. J. (1994) Purification of the N-type calcium channel associated with syntaxin and synaptotagmin. J. Biol. Chem. 269: 6306-6312

Lorenzon, N. M., Lutz, C. M., Frankel, W. N. and Beam, K. G. (1998) Altered calcium channel currents in Purkinje cells of the neurological mutant mouse leaner. J. Neurosci. 18 4482-4489

Martin, T. F. J. (1994) The molecular machinery for fast and slow secretion. Curr. Opin Neurobiol. 4: 626-632

Martin M. N., Charvin, N., Leveque, C., Sato, K., Nishiki, T., Kozaki, S., Takahashi, M. and Seagar, M. J. (1996) Interaction of SNARE complexes with P/Q-type calcium channels in rat cerebellar synaptosomes. J. Biol. Chem. 271: 6567-6570 Mochita, S., Sheng, Z. H., Baker, C., Kobayashi, H. and Catterall, W. A. (1996) Inhibition of neurotransmission by peptides containing the synaptic protein interaction site of $\mathrm{N}$-type $\mathrm{Ca}^{2+}$ channels. Neuron 17: 781-788

Monyer, H. and Lambolez, B. (1995). Molecular biology and physiology at the single-cell level. Curr. Opin. Neurobiol. 5: 383-387
Mori, Y., Friedrich, T., Kim, M. S., Mikami, A., Nakai ,J., Ruth, P., Bosse, E., Hofmann, F., Flockerzi ,V., Furuichi, T., Mishikiba, K., Imoto, K., Tanabe, T. and Numa, S. (1991) Primary structure and functional expression from complementary DNA of a brain calcium channel. Nature 350: 398-402

Ophoff, R. A., Terwindt, G. M., Vergouwe, M. N., van Eijk, R, Oefner, P. J., Hoffman, S. M.,Lamerdin, J. E., Mohrenweiser, H. W., Bulman, D. E., Ferrari, M., Haan, J., Lindhout, D., van Ommen, G. J., Hofker, M. H., Ferrari, M. D. and Frants, R. R. (1996) Familial hemiplegic migraine and episodic ataxia type-2 are caused by mutations in the $\mathrm{Ca}^{2+}$ channel gene CACNL1A4. Cell 87: 543-552

Pai, A. C. (1965) Developmental genetics of a lethal mutation, muscular dydgenesis (mdg), in the mouse. I. Genetic analysis and gross morpho-logy. Dev. Biol. 11: 82-92

Perez-Reyes, E., Wei, X., Castellano, A. and Birnbaumer, L. (1990) Molecular diversity of L-type calcium channels. J. Biol. Chem. 265: 20430-20436

Perez-Reyes, E. Cribbs, L. L., Daud, A., Lacerda, A. E., Barclay, J., Williamson, M. P., Fox, M., Rees, M. and Lee, J. H. (1998) Molecular characterization of a neuronal lowvoltage-activated T-type calcium channel. Nature 391: 896-900

Ptacek, L. J., Tawil, R., Griggs, R. C., Engel, A. G., Layzer, R. B., Kwiencinski, H. and McManis, P. G. (1994) Dihydropyridine receptor mutations cause hypokalemic periodic paralysis. Cell $77:$ 863-868

Puro, D. G., Hwang, J.-J., Kwon, O.-J. and Chin, H. (1996) Characteri-zations of an Ltype calcium channel expressed by human retinal Muller cells. Mol. Brain Res. 37: 4148

Schoenherr, C. J., Paquette, A. J. and Anderson, D. J. (1996) Identification of potential target genes for the neuron-restrictive slince factor. Proc. Natl. Acad. Sci. USA 93: 98819886

Sather, W. A., Tanabe, T., Zhang, J. F., Mori, Y., Adams, M. E. and Tsien, R. W. (1993) Distinctive biophysical and pharmacological properties of class $A(B I)$ calcium channel alpha 1 subunits. Neuron 11: 291-303

Sheng, Z. H., Rettig, J., Cook, T. and Catterall, W. A. (1995) Calcium dependent interaction of N-type calcium channels with the synaptic core complex. Nature 379: 451454

Snutch, T. P. and Reiner, P. B. (1992) $\mathrm{Ca}^{2+}$ channels: diversity of form and function. Curr. Opin. Neurobiol 2: 247-253

Sollner T., Whiteheart, S. W., Brunner, M., Erdjument-Bromage, H., Geromanos, S. Tempst, P. and Rothman, J. E. (1993) SNAP receptors implicated in vesicle targeting and fusion. Nature 362: 318-324

Soong, T. W., Stea, A., Hodson, C. D., Dubel, S. J., Vincent, S. R. and Snutch, T. P. (1993) Structure and functional expression of a member of the low-voltage activated calcium channel family. Science 260: 1133-1136

Sudof, T. C. (1995) The synaptic vesicle cycle: A cascade of protein-protein interactions. Nature 375: 645-653

Tanabe, T., Beam, K. G., Powell, J. A. and Numa, S. (1988) Restoration of excitationconttraction coupling and slow calcium current in dysgenic muscle by dihudropyridine receptor complementary DNA. Nature 336: 134-139

Weiser, O., Bennett, M. K. and Atlas, D. (1996) Functional interaction of syntaxin and SNAP-25 with voltage-sensitive L- and N-type $\mathrm{Ca}^{2+}$ channels. EMBO J 15: 4100-4110

Wheeler, M. B., Sheu, L., Ghai, M., Bouquillon, A., Grondin, G., Weller, U., Beaudion, A. R., Benett, M. K., Trimble, W.S. and Gaisano, H. Y. (1996) Characterization of SNARE protein expression in b cells lines and pancreatic islets. Endocrinology 137: 1340-1348

Williams, M. E., Feldman, D. H., McCue, A. F., Brenner, R., Velicelbi., G., Elis, S. B. and Harpold, M. M. (1992) Structural and functional expression of $\alpha 1, \alpha_{2}$, and $\beta$ subunits of a novel human neuronal calcium channel subtype. Neuron 8: 71-84

Williams, M. E., Marubio, L. M., Deal, C. R., Hans, M., Brust, P. F., Philipson, L. H., Miller, R. J., Johnson, E. C., Harpold, M. M. and Elis, S. B. (1994) Structure and functional characterization of neuronal alpha $1 \mathrm{E}$ calcium channel subtypes. J. Biol. 
Chem. 269: 22347-22357

Zhuchenko, O., Bailey, J., Bonnen, P., Ashizawa, T., Stockton, D. W., Amos, C.,

Dobyns, W. B., Subramony, S. H., Zoghbi, H. Y. and Lee, C. C. (1997) Autosomal dominant cerebellar ataxia (SCA6) associated with small polyglutamine expansions in

the alpha $1 \mathrm{~A}$-voltage-dependent calcium channel. Nat. Genet. 15: 62-69 